\title{
A Structural Model of the Teaching Practice and Pro-Environmental Behavior in Elementary Mexican Students
}

\author{
Giovana Rocío Díaz Grijalva* \\ Institute Technological of Sonora, Ciudad Obregón, Mexico \\ Beatriz Camarena Gómez \\ Center of Research in Food and Development, Hermosillo, Mexico \\ Daniel González Lomelí \\ University of Sonora, Hermosillo, Mexico \\ Carlos Alberto Mirón Juárez \\ Institute Technological of Sonora, Ciudad Obregón, Mexico
}

\begin{abstract}
Almost four decades after having integrated environmental education in primary education in Mexico, it is important to prove the relationship between the environmental behavior shown by students and the environmental education they perceive, therefore, a structural equations model was designed and tested with information provided by 217 sixth grade students. The model showed regression coefficients between practice of environmental education and its causality directly and positively with values (0.035), skills (0.333), attitudes (0.269) and pro-environmental behavior (0.290). It is confirmed that the environmental education that is taught in a transversal way in schools is significant and that teaching practice should be promoted in the use of materials, institutional support and didactic resources focused on promoting environmental attitudes, skills and values in children.
\end{abstract}

Keywords: environmental education, teaching practice, pro-environmental behavior, students.

\section{Introduction}

In Mexico, the Ministry of Public Education approved in the early 80's the inclusion of environmental education in the elementary school plan and, in coordination with then Secretary of Urban Development and Ecology (SEDUE) and the Ministry of Health, they elaborated the National Environmental Education Program, taking shape in the 90 's with the reforms of all the curricula of the basic education system (preschool, elementary school and junior high school) up to the bachelor's degrees offered by 'normal' schools ${ }^{*}$ to train teachers. The purpose was to teach children and adults, values, attitudes, and relationships for coexistence and harmony with ecosystems (Calixto, 2012; Terrón \& González, 2009).

Within Mexican education, the purpose of encouraging knowledge, skills, attitudes, values, and behaviors in favor of the environment is proposed (Mazón, 2019). The syllabi and programs, particularly the textbooks, present a series of activities aimed at promoting attitudes that allow students to develop explanations with great precision about the natural and social phenomena that occur in their region. The teachers are reiterated that their job is to provide students with the knowledge to reflect about the

\footnotetext{
* Normal schools are public education institutions whose objective is to train teachers for preschool, primary, secondary and preparatory education. 
world and the consequences of the abuse of consumption, a result of human activity (Rigo, 2008; Martínez, Guevara, \& Valles, 2016).

In basic education, is promoted the integration of knowledge and experiences through a formative approach (attitudes, values, and rules) and seeks responsible environmental action in the face of the challenges of a changing society. Elementary education includes environmental content, as well as promoting values, attitudes, skills, and behaviors on the assumption that the experiences of students in their daily life, at home, school or another space of the social context to take care of their environment with tasks about garbage management, water saving, taking care of green areas, among other activities. The teacher's job is to promote school activities so it can have an impact on the personal responsibility of students in environmental actions and the social commitment to act in consequence against pollution; in addition to encourage their critical thinking and development of skills; as well as the analysis and logical reasoning to solve problems on their daily life (Calixto, 2012; Díaz, Camarena \& Mirón, 2019). However, the impact of this specific school practice in environmental education on values, skills, knowledge and attitudes exhibited by students has been poorly studied. Due to the previously mentioned, the present study must investigate the causal relationship that these pedagogical processes have in the pro-environmental competencies of basic education students.

Environmental education through teaching practice should be promoted from an early age of human beings, a period in which children assimilate in a more possible way the values they have to build for the management and care of the environment, this due to the curiosity for the nature of their immediate environment, besides, conditions are generated to establish environmental values that will accompany them in their personal evolution (Rivera, 2018). Díaz, Ochoa \& Mirón (2020) refer that environmental education is relevant and fundamental to acquire behavioral changes in students of basic education. On the other hand, the findings mention that it is relevant to contemplate the didactic resources, the support of the institution, and the materials used by teachers with the environmental perception and frequent or recurrent contact with nature.

Knowledge is acquired in doing or working with nature, that is, carrying out day-to-day activities that are carried out by the student in a mechanical way, where its functionality is explained. It is important because the teacher knows the way to approach educational practice, that he or she has an environmental awareness and attitude, it is essential that the educators has a critical awareness about the environmental problem from their immediate context to the most general way, adding that they acquire theoretical elements that make easier the understanding of educational content that allow them to implement training actions for the development of the child. Ibáñez (2011), mentions, from the perspective of the evolution of education, that all teaching practice aims for students to learn, for this, each teacher uses the necessary resources to achieve this goal.

Rayas and García (2019) mention that teachers who work on environmental education in preschool and primary education present some difficulties that must be analyzed, in order to make proposals that allow different opportunities that this educational space has in terms of orientation for school communities, children and the general population on environmental problems. Education should be promoted as a horizontal and triangular slope, between the teacher, student, and nature, in a related communicative logic including popular, traditional and academic knowledge This possible association should lead to a wider relationship that derives socially in a society in harmony with nature in a context of well-being. 
Similarly, Galvis, Perales \& Ospina (2019) allude the importance that the teacher needs to promote the values of the community from which the children come and relate it to the preservation of nature, as well as to recognize the issues of their entity and be a constant reflection in which they must be prepared for a medium and long-term future. Galli, Campos, Bedin \& Catella (2013) contemplate children's environmental attitudes, reflect the importance of contact with nature to promote recurring relationships with the natural environment, with cognitive activation in environmental attitudes and pro-environmental behavior.

Environmental psychology has as its object of study the relationship between the physical environment and human behavior. The activities of individual's daily life are intertwined with the physical environments in which he or she lives and works, how the environment is perceived also determines the attitudes and environmental behavior that is fundamental to face daily events (Baldi \& García, 2006). Environmental psychology studies human behavior within the framework of delimited environmental problems or topics. When applied, environmental psychology is defined in terms of problems to be addressed: degradation of the environment, the habitability of settings, health, medical condition or illness and the environment, space designs, therefore, they are indicators that had been addressed in education. (Gallego, Gallego, Arboleda, Garcés \& Sepúlveda, 2016; Torres, Messina, Salamanca \& Sepúlveda, 2015; Díaz, Camarena, Mirón and Ochoa, 2019, Corral, 2001; Corral, 2004).

From the psychological approach, skills, knowledge, beliefs, attitudes, and self-efficacy are fundamental factors in the explanation of environmental problems. These variables are the object of study of the disciplines that investigate human behavior. Environmental psychology can be defined as the discipline that studies the reciprocal relationships between people's behaviors and the socio-physical environment, both natural and built (Aragonés \& Ámerigo, 1998; Sánchez, 2014).

The values represent a dimension of the behavioral practices that socially regulate the transmission, reproduction, and practice of behavior that affect groups of individuals, according to the relative position they occupy in the social structure. For Rodríguez (2006), values as behavioral practices are acquired in the context of precise interactions with specific individuals who impose norms or examples of behavior as a necessary social mode, that is, as a "must be" of interactions. Behavior, as indicated, has no intrinsic value, it is neither good nor bad, unadaptive, or adaptive.

The teacher demonstrates or exemplifies the value on students through academic speech, videos, teamwork, or individual work. Also, the teacher demonstrates explicit behaviors with the values that are intended to be taught, as well as demonstrations with the participation of the teacher and some students in the classroom where the value is made explicit in the student's everyday situations (Gómez, 2017; Touguinha \& Pato, 2011).

Researches indicate that people who are most receptive to change their conducts or behaviors, in this case environmental ones, are the youngest (Doherty \& Clayton, 2011). Therefore, developing a critical analysis of what motivates pro-environmental behavior among young people is an important area that must be taken into account in the practice of the learner in the classroom to create a green future (De Leeuw, Valois, Ajzen \& Schmidt, 2015).

The skills, considered as effective sequences of actions, can be practiced in specific situations or circumstances that include precise and specific problems that can determine the skills required (observe, generate, evaluate, diagnose, care) to promote behaviors of caring for the environment (Stern, Powell \& Hill, 2014; Corral, Varela, \& 
González, 2002). Palacios and Bustos (2012) mention that few studies consider some types of pro-environmental skills such as; water-saving, electricity-saving, and waste separation, which are a reference when incorporating this variable in models to understand pro-environmental behavior, also, is mentioned that skills are key elements for environmental conservation.

The role of attitudes in the formation of pro-environmental behavior can be explained through the Reasoned Action Theory (TAR) of Ajzen and Fishbein (1980). Attitudes about behavior, subjective norms and behavioral control allow influencing the behavioral intention generating behaviors (Campos, Pasquali, \& Peinado, 2008). Galli, Bolzan, Bedin, \& Castellá (2013) point out that environmental attitudes refer to beneficial or non-beneficial feelings towards some characteristics of the physical environment or towards an environmental problem. The attitudes, skills and values are a tiny part of the components of a pro-environmental action. On this sense, it is considered that pro-environmental behaviors or behavioral intentions indicate willingness in the way of acting firmly concerning on the attitude towards the environment. Therefore, it is emphasized that, due to the specificity of environmental attitudes, some studies tend to link pro-environmental attitudes and behaviors.

As an important variable to environmental education, knowledge is explained as the retention or capture of the information that we perceive from the environment and is referred as social representation (Moscovici, 1984; Arcury \& Johnson, 1987; Pothitou, Hanna \& Chalvatzis, 2016; Paco \& Lavrador, 2017). The knowledge is obtained from the interaction with the environment, the knowledge of the skills is part of the predictive variables of pro-environmental behavior. For Díaz and Hernández (2002), learning techniques are those used by the teacher to ease knowledge; for example, concept maps, comparative charts, synoptic charts, summaries, essays, semantic networks, among others. The techniques applied in environmental education can be adjusted to the needs that are required in the classroom by the teacher, adjusting to the problem to be solved.

Similar to knowledge, other important variable related with how students interact with environmental content is reflection, understood as an operation that pays special attention to the questions planted by reality, to the effectiveness of the action on it, and the experiences of the protagonist, it is effective to have meaningful learning (Paéz \& Puig, 2015). In environmental education, once the problem or the specific situation has been structured, it will require reflection from the student and feedback from the teacher, which will allow adherence to the knowledge acquired, thus giving meaningful learning.

Other internal process is problem-solving, which refers to the ability of the student to make decisions in a problem situation in which there is two or more alternatives to achieve a certain objective. (Díaz, 2006; Díaz \& Hernández, 2002). Problem-solving is of great importance because a series of contextualized environmental problems are presented in the students' locations; teachers and institutions must refer and propose an active or hypothetical solution to their students, encouraging reflection.

As an external factor to the teacher task, literature refer the institutional support as an fundamental element, and refers to the actions or implementations proposed by the formal education schools, which commit to promote environmental education, actions that can be observed from the teaching and school work where they promote water care, garbage collecting, light saving, among other activities inside and outside the campus, making an active student in school campaigns (González, 2007; González \& Arias, 2009).

Other factors related and needed to the teacher-student interaction are the materials and resources, particularly didactic ones, although they are relevant, they do not have 
special value by themselves. Their use is significant when they are properly integrated into the educational process, which must be compatible, in turn, with the wider environment that surrounds it and contributes to the teaching-learning process (school, regional, social, etc.). The materials can be digital, (computer, digital board, projector); hearing aids, image material, among others (Díaz \& Hernández, 2002; Castro, Rodríguez, Rodríguez \& Pose, 2007).

The points mentioned above represent a challenge within the study of formal environmental education, since the role of the teacher as a mediator in the development of the student's pro-environmental competences, assumes the student as the main actor in their education, which is why it becomes the main reference of the abilities and performance of the didactic tasks in the teacher's practice, which should be aimed at solving the pedagogical needs of the student.

In traditional Mexican education, it is seen as a didactic interaction in the application of environmental education in a transversal way. In basic education, the intellectual connection flows between knowledge, skills, attitudes, and values (Andráde, 2008, Calixto, 2012, Mazón, 2019). The teaching-learning process has been supported by an idea of unidirectional knowledge exchange, in which the teacher is a transmitter and the student an autonomous being capable of building their own knowledge (Retana, 2011; Ibáñez, 2007). SEP (2017) broadly mentions that within primary education the student will recognize the importance of caring for the environment by identifying local and global problems, as well as solutions that can be put into practice (for example, turn off the lights and not waste water).

\section{Methodology}

The research is of a non-experimental transactional type and is governed by the multiple causality modality, which implies that the analysis design is reconstructed based on the wide variability of the independent and dependent variables -not of a specific variable-, to evaluate the complete causal structure (León and Montero, 2003 in Hernández, Fernández, \& Baptista, 2010; Medrano \& Muñoz, 2017).

\section{Participants}

The population was sixth-grade elementary school students from Hermosillo city. The selection criterion for the study participants was that, in the school year precedent to the recollection of data, that is, students had completed the fifth grade of elementary school. The student's sample was simply random (selected randomly from the attendance list). 217 students were considered, 103 women and 114 men belonging to eight schools in an urban context, and three in a rural context, all public. The application of questionnaires had the authorization of the school authorities (teachers and management), signed informed consent, and consent of the parents.

\section{Model to propose in the study}

The objective of the study is to demonstrate the relationship that environmental education that is exercised in elementary schools has concerning to the proenvironmental values, skills, knowledge, and attitudes that students exhibit at the end of such school training and its relationship with their pro-environmental behavior. It is assumed that this relationship is significant and, to prove it, a structural equation model was designed (Figure 1) that statistically allows to estimate this possible effect and relationships between attitudes, values, skills, and knowledge and pro-environmental practices carried out in the school center perceived by the students. 


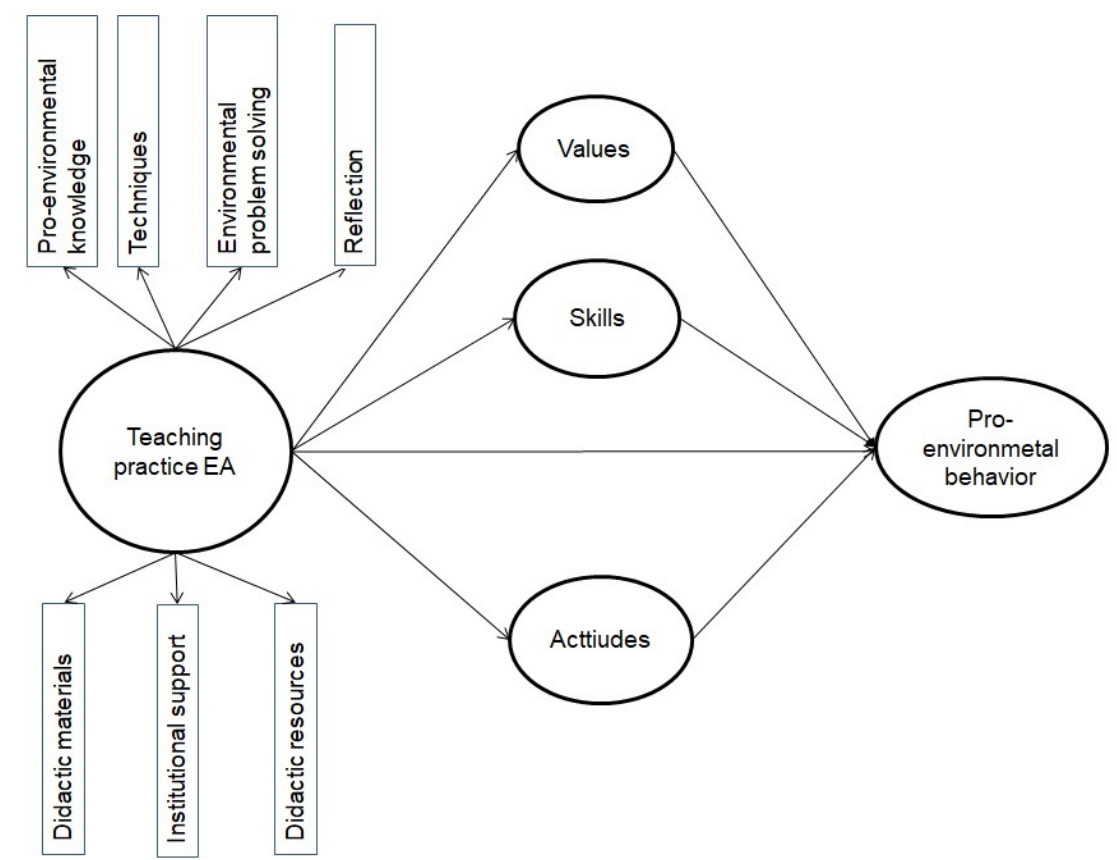

Figure 1. A theoretical model of multiple casualties to be tested: the practice of environmental education and values, skills, attitudes, and knowledge with proenvironmental behavior.

\section{Data Analysis}

In order to carry out such analysis procedure, the internal consistency of the scales used was first assessed; later the basic statistical estimates and confirmatory factor analysis were performed. Finally, the model test was performed, which includes the measurement of goodness of fit between the inclusive model and the restricted or proposed model.

It is important to specify that an inclusive model refers to a total interrelation of observed factors and variables, even when it is accepted that the type of proposed relationships is presented minimally in reality, this is so since what is sought in science, based on the principle of parsimony, is to identify simple models that explain them as much as possible (Escobedo Hernández, Estebané, \& Martínez, 2016; Medrano \& Muñoz, 2017).

To know if the resulting model differs or is similar to the theoretical model, the statistical indicators (goodness of fit) must present an absolute fit of $p>0.05$ in the Chisquare $\left(X^{2}\right)$ between degrees of freedom less than three; In addition to perform a comparative adjustment using the Bentler-Bonet Normed Adjustment Index (IBBAN), the Bentler-Bonet Non-Normed Adjustment Index (IBBANN) and the Comparative Adjustment Index (IAC), which must be > 0.90 ( Ruiz, Pardo, \& San Martin, 2010), included in the EQS program (Bentler, 1993 in Ruiz, Pardo, \& San Martín, 2010). In other words, indices produce results ranging from 0 to 1.0 , and .90 is accepted as a suitable index of fit.

The data used in the model was obtained with a survey composed of five scales applied to students (knowledge, values, skills, behavior, and attitudes) (Fraijo, Corral, Tapia and García, 2012); as well as another survey on the perception of teaching practice in environmental education that covers pro-environmental knowledge, didactic techniques, reflection, problem-solving, didactic resources, support material and institutional support by Camarena (2009) and Díaz, Camarena, Mirón \& Ochoa (2019).

\section{Findings}


The structural equation model proposed aims to prove that pro-environmental values, attitudes, skills, knowledge, and behavior are directly and positively affected by the practice of environmental education carried out by the teacher in the school. Next, previous to the analysis of interest, the components of each variable, and the resulting regression indices between environmental education and environmental behavior are described.

In the first part of the model (figure 2), it can be seen that the correlation value of the practical variable of environmental education concerning the pro-environmental behavior variable was .297. According to Escobedo, Hernández, Estebané, \& Martínez. (2016), such value is significant when having an absolute fit $p<.05$ with Chisquare $\left(\mathrm{X}^{2}\right)$ of 1532.591 and 1196 degrees of freedom $(\mathrm{gl})$, the parsimonious adjustments are an indicator of the Bentler-Bonett norm fit (IBBAN), 0.672, the BentlerBonett non-standard fit indicator (IBBANN) was 0.894, the comparative fit indicator (IAC) was 0.901 and the root of the RMSEA approximation square residual was 0.038 within the range 0.032 to 0.048 .

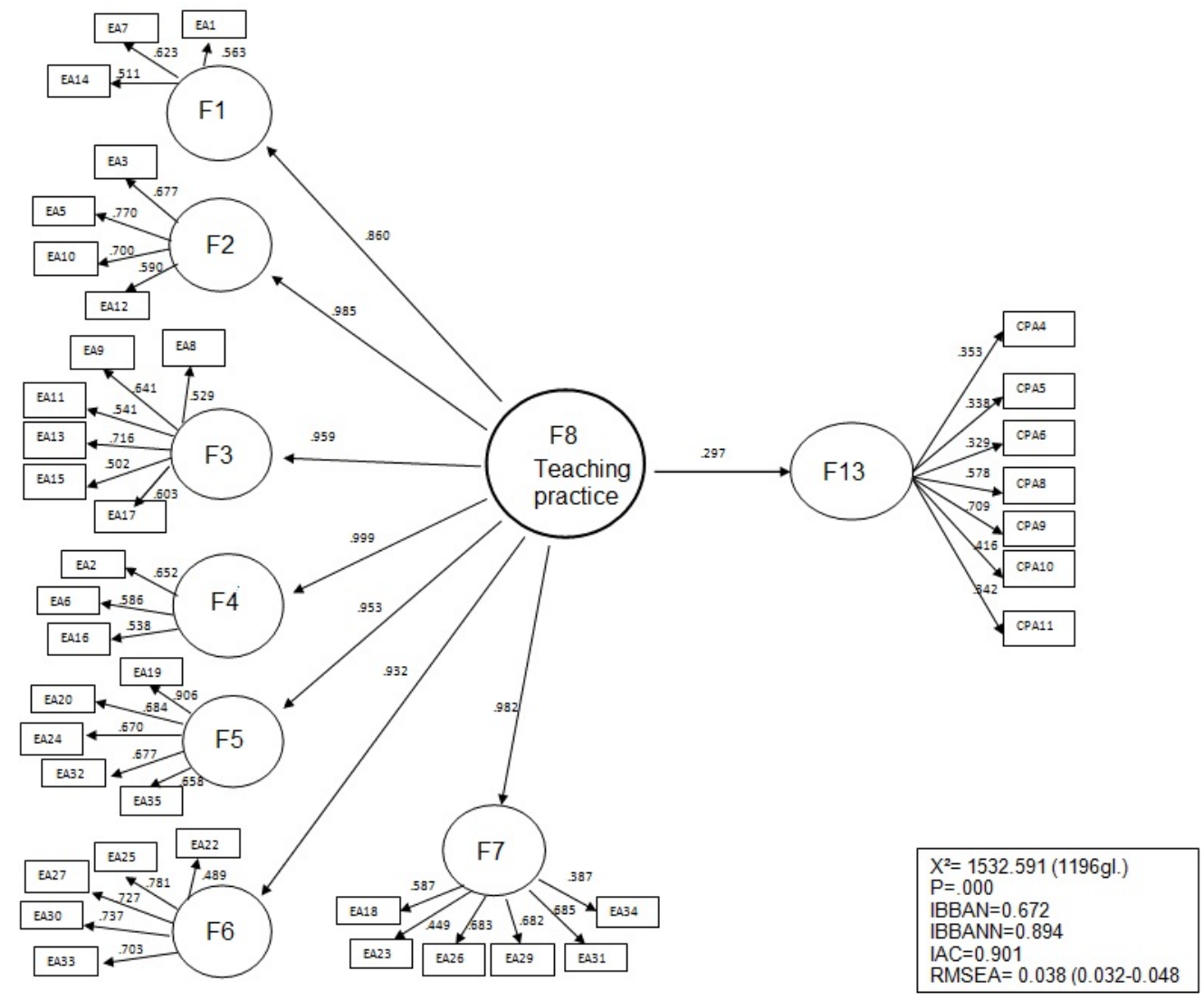

Figure 2. Factors of environmental education practice and pro-environmental behavior

Each of the independent factors that make up the practical construct in environmental education reached a high structural coefficient: 860 in knowledge about environmental issues (F1); .955 in techniques provided in school (F2); .959 in solutions to environmental problems (F3); .999 in reflection on environmental issues and possible solutions (F4); .953 in teaching materials (F5); .932 in institutional support (F6); and .982 in teaching resources (F7). When observing in detail the components of each of these coefficients and their respective indicators, it is observed that the majority were $\geq 500$, only three presents $\leq 500$. 
The knowledge factor on environmental problems (F1), made up of three components, presents the following: garbage management (EA7) .623; water care (EA1) .536; and water shortage (EA14) .511. The technical factor provided in the school (F2) is made up of four components, two related to environmental awareness talks, one refers to workshops, and the other to the elaboration of posters. The talk about water problems (EA5) has a structural coefficient of .770; the talk about the garbage problem (EA10), shows a weight of .700; handicraft workshops in response to environmental problems (EA3) .677; and the preparation of posters for the awareness of water care (EA12) .590 .

In the solutions factor on environmental problems (F3), made up of seven components, it is observed: task-challenge to find solutions (EA13, .716); motivation to take care of water (EA9, .641); environment care (EA17, .603); among others. Just as in the three components of the factor, lets reflect on socio-environmental problems and their possible solutions (F4), the index is observed by reflecting through poetry (EA2, .652); we wrote poetry about the community $(E A 6, .586)$ and we reflected on how we affect the ecosystem (EA16; .538).

The component of the didactic materials factor (F5) was made up of making brochures to aware of and combat the school's water shortage (EA19, .906); we consulted the books in the reading corner to learn about the environmental situation of Sonora and Mexico (EA20; .584); We consulted books and magazines to learn about the water shortage in the State of Sonora (EA24; .570); We access web pages in the computer center to learn about the problems of water and garbage in Hermosillo and Sonora (EA32; .577) and we made posters to combat water scarcity and/or spread the proper management of garbage (EA35; .658)

In the following two factors, institutional support (F6) and didactic resources (F7), most of their respective structural components obtained $\geq .585$, only one of the five components corresponding to institutional support resources was 489; and two of didactic resources were $\leq .449$.

Regarding the pro-environmental behavior variable (F13), the structural coefficient of its respective components was generally lower, in order from highest to lowest the following is observed: I read books or stories about nature (CPA9, .709); I watch environmental programs or videos (CPA8, .578); I recycle materials in tasks and models (CPA10, .416); I throw away the trash to avoid pollution (CPA4, .353); I turn off electronic devices when not using them (CPA11, .342); I leave the sink tap open (CPA5, .338); I leave the faucet open when I soap up (CPA6, .329).

In the second part of the model (Figure 3), when making the estimates corresponding to the structural model regarding the practical construct of environmental education, a direct and positive relationship was observed with values (F9), skills (F10) and attitudes (F11), whose correlations were $.035, .333$, and .269, respectively. At the same time, a relationship was observed between the latter two with skills and attitudes with the pro-environmental behavior variable, with a structural coefficient of .421 and .431; only the variable values did not present a significant relationship (marked in the model with a dashed line). 


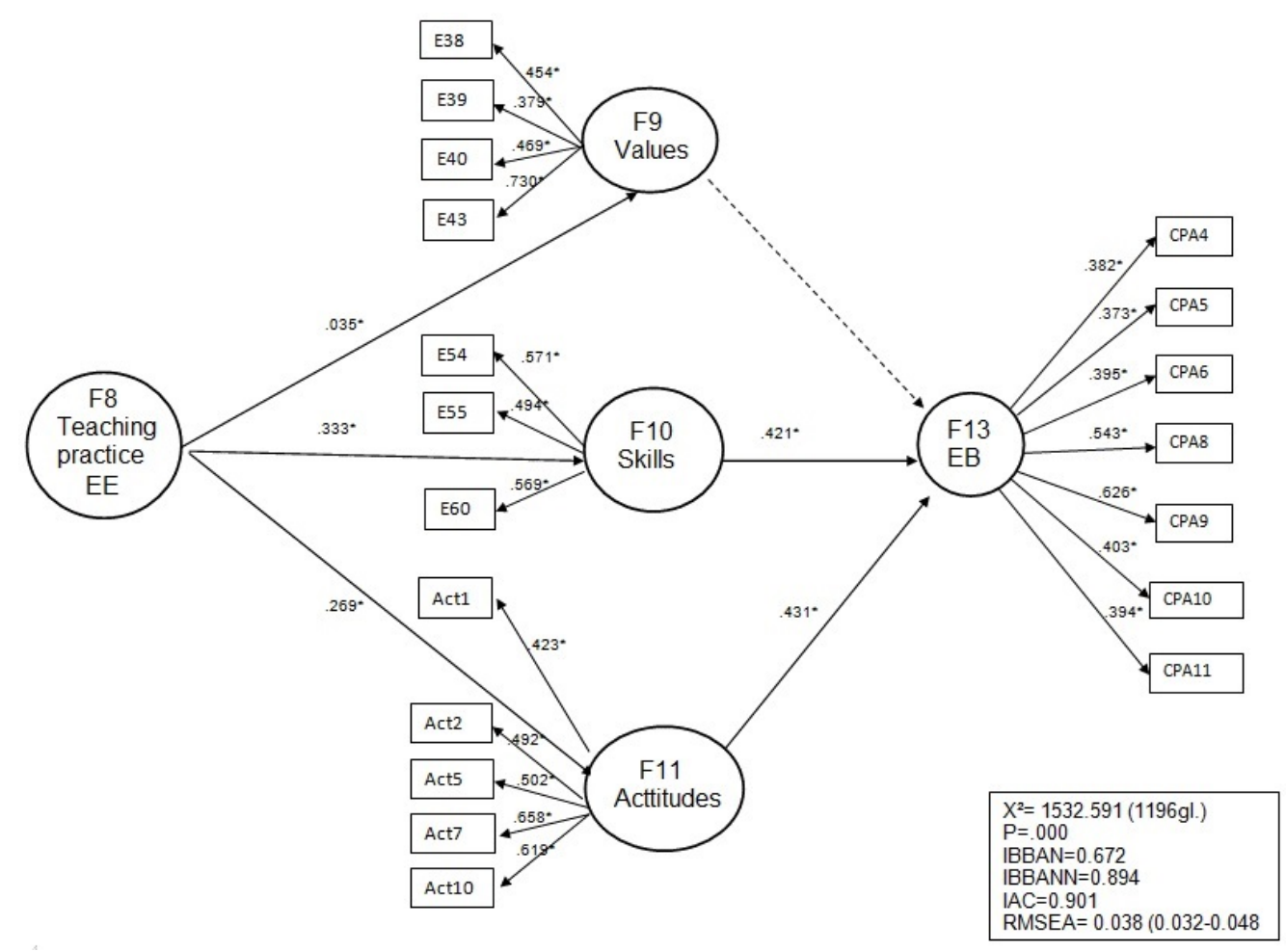

Figure 3. The second part of the structural model. Practice in environmental education.

Regarding the objective of the study, the estimates results from the model (Figure 4) show that practical construct in environmental education is directly and positively related to pro-environmental values, skills, attitudes, and behavior.

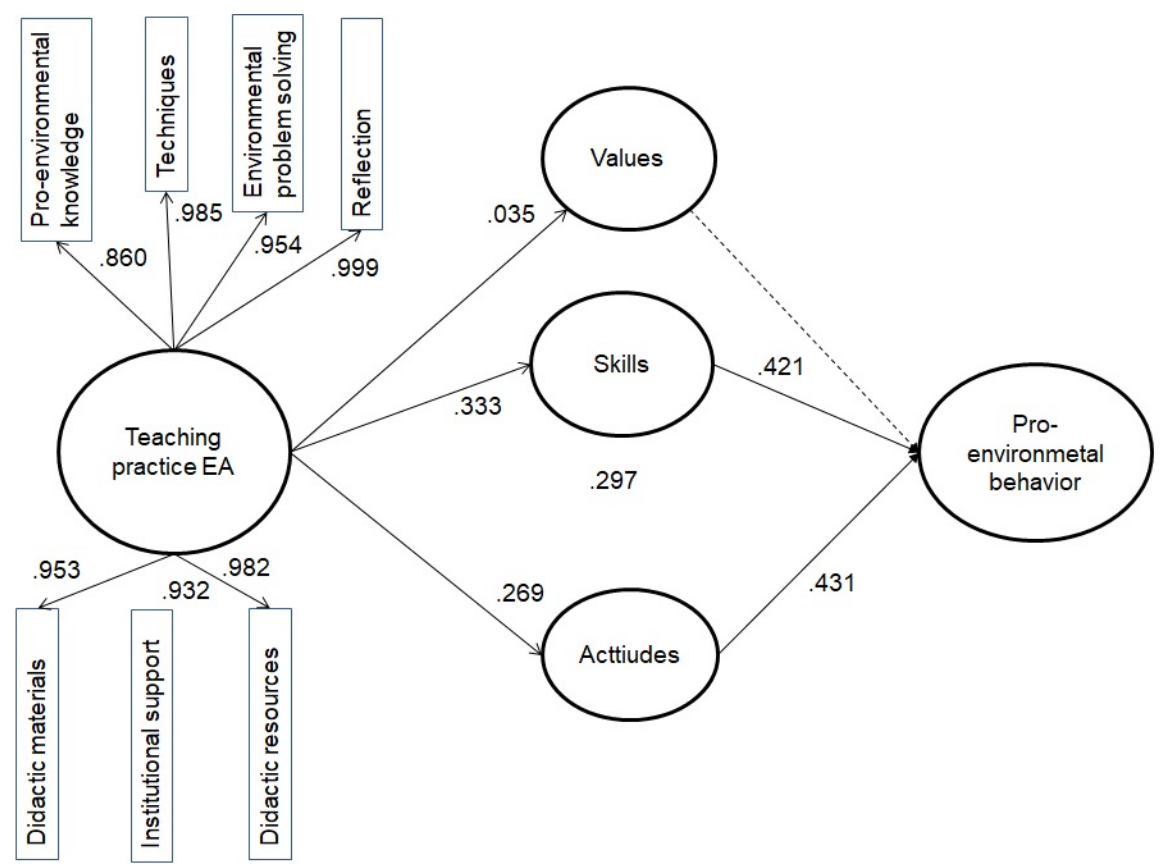

Figure 4. Structural model of environmental education practice and pro-environmental behavior. 


\section{Conclusions and Discussion}

The findings tossed beneficial indices on the relationship obtained by proenvironmental attitudes, skills and behavior with teaching practice in environmental education, which indicates precisely that they are acquired and strengthened in school environments to face environmental problems to be solved in their community (Galvis, Perales \& Ospina, 2019; Calixto, 2012; Díaz, Camarena \& Mirón, 2019). The explicit values in the elementary school curriculum (justice, tolerance, honesty, respect for human dignity and cultural and natural diversity) stand out in the structural model with very low regression rates, of which the evaluated dimensions were "avoid pollution", "protect the environment", "respect", "peace", "unity with nature"; while "power" and "wealth". These results confirm what was stated by Mazón (2019; Torres, Messina, Salamanca \& Sepúlveda, 2015) concerning a curriculum that fosters universal and proenvironmental values that are integral to the training of the student but at a personal level within a very diverse curriculum that has the objective of landing it in a particular way for those educated in a country as culturally diversified as Mexico, it cannot be taken for granted that the values are the same for all elementary school students, which is why it is suggested to address much more in the study of this variable for possible research.

Regarding environmental skills, the theory refers to them as the most predictive factor towards pro-environmental behavior (Corral, 1996 and 2001; Hines, Hungerford, \& Tomera, 1987). It is no coincidence that the curriculum in Mexican elementary schools will continue to be reinforced with activities that generate such skills inclined to solve everyday problems such as water pollution, saving water, managing garbage, caring for electrical energy among others (SEP, 2008; SEP, 2016, Juárez, 2010, Fraijo, Corral, Tapia and Garcia, 2012, Erdogan, 2015). The relationship obtained by the environmental ability for teaching practice in environmental education was beneficial, which tells us that we must continue to strengthen didactic strategies, didactic materials, reflection, institutional support to encourage environmental activities to solve a particular problem in the student's environment. The need is evident for teachereducational authorities to reinforce and promote educational actions that motivate/ease the skills expected in students.

About pro-environmental attitudes, it was obtained a positive regression coefficient in favor of the teaching practice in environmental education, this means that the dimensions of the attitudes such as concern for the care of water (use of vital liquid) and the garbage had an impact on the student body by the teaching practice through various didactic strategies used. Teachers in their didactic strategies must focus on addressing local or community problems such as garbage and efficient use of water, droughts in the region, and water pollution, being able to have a synergy of collaboration with local, educational authorities and society in general. Attitudes can act as a positive direction in children to be more sensitive to local problems, as long as they are reinforced by teaching practice and very possibly by the family (Rigo, 2008; Martínez, Guevara, \& Valles, 2016, Duarte \& Sanagustín, 2017; Schmitz \& Rocha, 2018; Mazón, 2019).

The points mentioned above can be linked to what is observed in the variable knowledge, addressing the dimensions of waste management and water problems that students refer to, an inquiry that also resulted from the information that is handled as basic in the textbooks of third to sixth grade of elementary school. The study showed that it did not present sufficient reliability for the variable to be considered in the structural model, therefore it was excluded, although some authors point out that this variable has presented reliability, in this particular study it was not achieved (Torres, Messina, Salamanda \& Sepúlveda, 2016; Fraijo, Corral, Tapia, Díaz \& Sánchez, 2008) 
In the structural equations model, the environmental knowledge scale obtained an alpha of .44 , that is, not desired by the program. Undoubtedly, how to promote the appropriation of knowledge is a complex issue that requires much more analysis.

Pro-environmental behavior, as a variable dependent on dispositional factors, makes it possible to identify whether the child or adult correctly performs the skills, knowledge, attitudes and values promoted by the environment. The pro-environmental behaviors that were addressed in the study were about taking care of the light, particularly "closing the refrigerator door when looking for something to eat" and "turning off the lights in the room when it is not being used". Water care behaviors were not significant. However, it obtained a significant structural coefficient with the teaching practice in environmental education, which is beneficial in order to continue to reinforce the great diversity of strategies, reflection, as well as problem-solving to obtain better results in generating adequate pro-environmental behaviors in the student body (Díaz, Camarena \& Mirón, 2019; Erdogan, 2015).

The model factors that showed significant relationships were "knowledge of environmental problems", "techniques used in the classroom", "solutions to environmental problems", "reflection", "didactic materials", "institutional support" and "didactic resources". which were consolidated as a construct generating in turn the teaching practice in environmental education with relationships greater than ninety. For its part, the "teaching practice in environmental education" had a significant relationship with pro-environmental behavior (0.297) (figure 4).

This means that by having the indicators of environmental practice consolidated, proenvironmental behavior is reinforced. However, it is important to point out that the study of teaching practice in environmental education refers to what the students perceived from the classes or activities they carried out with their respective teachers; For all that, this first lens of approximation to the relationship of such variables allows us to consider that there is consistency in the environmental education actions carried out by teachers in the classroom and/or school, apparently their concern for contemporary environmental problems. It is what has motivated them to practice such practice. Even the teachers themselves consider that they lack greater knowledge on this matter, that they need to be better prepared in pedagogical and didactic aspects to improve their school practices in environmental education (Calixto, 2012; Calixto, 2015; Mazón, 2019).

The model can allow the attitudes, values, and environmental skills exhibited by elementary school students to be statistically significant related to the practice of environmental education in the school classroom (associated with the teacher). In particular, the daily school work carried out by teachers in schools directly affects the formation of pro-environmental attitudes and behaviors of students. The hypothesis is confirmed by showing the presence of a significant relationship between the environmental dispositional variables of the students and the school practice in environmental education that they have received, at least in the immediately preceding school year.

These findings confirm the importance of carrying out a good practice of environmental education in initial training school systems; and, therefore, the need to strengthen teaching strategies, teaching resources, support materials, addressing problemsolving, the knowledge of basic education teachers in this matter as referred to by the participating elementary school teachers themselves in this and other future studies.

\section{Acknowledgements:}

To the Development Research Center (CIAD, A.C) for its support and the National Council of Science and Technology (CONACYT) for financial support. 


\section{References}

Arcury, T. A., \& Johnson, T. P. (1987). Public Environmental knowledge: A statewide survey. The Journal of Environmental Education, 18(4), 31-37. doi: https://doi.org/10.1080/00958964.1987.9942746

Andráde, C. (2008). El enfoque por competencias en educación (The competency approach in education). Ideas CONCYTEG, 3(39), 60-64. Retrieved from http://www.esc.geologia.efn.uncor.edu/wp-content/uploads/2013/05/el-enfoquepor-competencias-en-educacion.pdf

Baldi, L. G., \& García, Q. E. (2006). Una aproximación a la psicología ambiental. (An approach to environmental psychology) Fundamentos en Humanidades, $713-$ 14), 157-168. Retrieved from https://dialnet.unirioja.es/servlet/articulo?codigo $=2309513$

Calixto, F. R. (2012). Investigación en educación ambiental (Research in environmental education). Revista mexicana de investigación educativa, 17 (55), 1019-1033. Retrieved from http://www.scielo.org.mx/pdf/rmie/v17n55/v17n55a2.pdf

Calixto, F. R. (2015). Propuesta en educación ambiental para la enseñanza del cambio climático (Proposal in environmental education for teaching climate change). Diálogos educativos, (29), 54-68.

Castro, R., Rodríguez, R., Rodríguez, S. \& Pose, B. (2007). La elaboración de materiales didácticos por los propios alumnos y profesores (The development of teaching materials by the students and teachers themselves). Revista Aula. (165), 21-27.

Camarena, Beatriz. (2009). Educación Ambiental y Formación de Profesorado en México: Estudio de Perfiles Ambientales en las Escuelas Normales de Sonora (Tesis Doctoral en Educación) (Environmental Education and Teacher Training in Mexico: Study of Environmental Profiles in the Normal Schools of Sonora; Doctoral Thesis in Education). Universidad de Salamanca, Salamanca, España.

Campos, M., Pasquali, C., \& Peinado, S., (2008) Evaluación psicométrica de un instrumento de medición de actitudes pro ambientales en escolares venezolanos (Psychometric evaluation of an instrument for measuring proenvironmental attitudes in Venezuelan schoolchildren). Paradigma 9 (2), Retrieved from http://ve.scielo.org/scielo.php?script=sci arttext\&pid=S101122512008000200008

Corral, V. (1996). Un modelo estructural de reuso y reciclaje en México (A structural model of reuse and recycling in Mexico). La Psicología Social en México, 423437.

Corral, V. V. (2001). Comportamiento Proambiental (Environmental Behavior). Santa Cruz de Tenerife, España: Resma.

Corral, V, V. (2004). Teorías explicativas de la interacción persona, cultura y medio ambiente: Análisis y propuestas (Explanatory theories of person, culture and environment interaction: Analysis and proposals). Persona, Sociedad y Medio Ambiente. Perspectivas de la investigación social de la sostenibilidad, 14-23.

De Leeuw, A., Valois, P., Ajzen, I., \& Schmidt, P. (2015). Using the theory of planned behavior to identify key beliefs underlying pro-environmental behavior in highschool students: Implications for educational interventions. Journal of environmental psychology, 42, 128-138

Díaz, B. F. (2006). Enseñanza situada: vínculo entre la escuela y la vida (Situated teaching: a link between school and life). México: McGraw-Hill. 
Díaz, G., Camarena, G. \& Mirón, J. (2019). Educación ambiental: la práctica docente y la perspectiva del estudiante (Environmental education: teaching practice and the student's perspective). En Calixto, F. \& Martínez, H. (Eds.), Educación Ambiental en las escuelas de nivel básico, (91-111). México: Red Durango de Investigadores Educativos.

Díaz, G., Camarena, G., Mirón, J., y Ochoa, Ávila, Eneida. (2019). Prácticas docentes en educación ambiental y habilidades proambientales en el estudiantado de quinto grado de primaria (Teaching practices in environmental education and pro-environmental skills in fifth-grade primary school students). Revista Actualidades Investigativas en Educación, 19(3), 1-18. Doi. 10.15517/aie.v19i3.38797

Díaz, B. F., \& Hernández, G. (2002). Estrategias docentes para un aprendizaje significativo (Teaching strategies for meaningful learning). México: McGraw Hill.

Duarte, R., Escario, J. J., \& Sanagustín, M. V. (2017). The influence of the family, the school, and the group on the environmental attitudes of European students. Environmental Education Research, 23(1), 23-42.

Erdogan, M. (2015). The Effect of Summer Environmental Education Program (SEEP) on Elementary School Students' Environmental Literacy. International Journal of Environmental and Science Education, 10(2), 165-181.

Escobedo, P. M., Hernández, G. J., Estebané, O. V., \& Martínez, M. G. (2016). Modelos de ecuaciones estructurales: Características, fases, construcción, aplicación y resultados (Structural equation models: Characteristics, phases, construction, application and results). Ciencia \& trabajo, 18(55), 16-22. doi: http://dx.doi.org/10.4067/S0718-24492016000100004

Fraijo, S., Corral, V., Tapia, F., \& García, V. (2012). Adaptación y prueba de una escala de orientación hacia la sustentabilidad en niños de sexto año de educación básica (Adaptation and testing of a scale of orientation towards sustainability in children of sixth year of basic education). Revista mexicana de investigación educativa, 17(55), 1091-1117.

Fraijo, S., Corral, V., Tapia, C., Díaz, G. \& Sánchez, S. (2008). Competencias proambientales en niños de sexto grado de primaria (Pro-environmental competencies in sixth grade primary school children). Revista Mexicana de Psicología, núm. especial, pp.558-560

Gallego, R., Gallego, Q., Arboleda, L., Garcés, G. \& Sepúlveda, A. (2017). La influencia de la psicología ambiental en el contexto de la educación en Colombia: el caso del centro de Medellín (The influence of environmental psychology in the context of education in Colombia: the case of the center of Medellín). Producción + Limpia, 1(12), 124-132. Doi: https://doi.org/10.22507/pml.v12n1a13

Galli, F., Bolzan de Campos, C., Bedin, L., \& Castellá, J. (2013). Actitudes hacia el medio ambiente en la infancia: un análisis de niños del sur de Brasil (Attitudes towards the environment in childhood: an analysis of children from southern Brazil). Revista Latinoamericana de Psicología, 45, 461-473. Retrieved from http://publicaciones.konradlorenz.edu.co/index.php/rlpsi/article/view/1487/935

Gómez, E. L. (2017). Educación en valores (Education in values). Revista RA/TES, 3(6), 69-87. Retrieved from http://www.itcelaya.edu.mx/ojs/index.php/raites/article/view/720

González, G. E. (2007). Educación ambiental. Trayectorias, rasgos y escenarios (Environmental education. Trajectories, traits and scenarios), México: Universidad Autónoma de Nuevo León.

González, G. E., \& Arias, O. M. (2009). La educación ambiental institucionalizada: actos fallidos y horizontes de posibilidad (Institutionalized environmental education: failed acts and horizons of possibility). Perfiles educativos, 31(124), 
58-68.

Retrieved

from

http://www.scielo.org.mx/scielo.php?script=sci arttext\&pid=S018526982009000200005

Hernández, S. R., Fernández C. C., \& Baptista, L. P. (2010). Metodología de la Investigación (Investigation methodology). (5a Edición). México: D.F: McGrawHill.

Hernández, B., \& Hidalgo, M. C. (2010). Actitudes y creencias hacia el medio ambiente (Attitudes and beliefs towards the environment). En Aragonés, T. \& Amerigo, C. (Eds.), Psicología Ambiental, (309-330). Madrid: Pirámide.

Hines, J. M., Hungerford, H. R., \& Tomera, A. N. (1987). Analysis and synthesis of resarch on responsible enviromental behavior: A meta-analysis. Journal of Enviromental Education, 18, 1-8. doi: https://doi.org/10.1080/00958964.1987.9943482

Ibáñez, B. (2007). Metodología para la planeación de la educación superior, una aproximación desde la psicología interconductual (Methodology for planning higher education, an approach from interbehavioral psychology). (20-28). México: Mora-Cantúa Editores.

Martínez, C. G., Guevara, A., \& Valles, O. M. (2016). El desempeño docente y la calidad educativa (Teaching performance and educational quality). Ra Ximhai, 12(6), 123-134. Retrieved from https://www.redalyc.org/pdf/461/46148194007.pdf

Mazón, S. G. (2019). Estrategias didácticas en educación ambiental en el nivel básica (Didactic strategies in environmental education at the basic level). En Calixto, F. \& Martínez, H. (Eds.), Educación Ambiental en las escuelas de nivel básico, (281-307). México: Red Durango de Investigadores Educativos.

Medrano, L., \& Muñoz, N. (2017). Aproximação conceitual e prática aos modelos de equações estruturais (Conceptual and practical approach to structural equation models). Revista Digital de Investigación en Docencia Universitaria, 11(1), 219239. Retrieved from https://dialnet.unirioja.es/servlet/articulo?codigo $=5985638$

Retana, J. Á. (2011). Modelo educativo basado en competencias: importancia y necesidad (Competency-based educational model: importance and need). Actualidades investigativas en educación, 11(3). Retrieved from https://www.redalyc.org/articulo.oa?id=44722178014

Rigo, L. (2008). Constructivismo educativo, actividad y evaluación docente: relato de algunas posibles incongruencias (Educational constructivism, activity and teacher evaluation: a report of some possible inconsistencies). Reencuentro, Núm. 53, Retrieved from https://www.redalyc.org/pdf/340/34005311.pdf

Rodríguez, C. (2006). Análisis Contingencial (Contingency Analysis). México: Universidad Nacional Autónoma de México.

Ruiz, M., Pardo, A., \& San Martin, R. (2010). Modelos de Ecuaciones Estructurales (Structural Equation Models). Papeles del Psicólogo, 31, 34-45. Retrieved from https://www.redalyc.org/pdf/778/77812441004.pdf.

Ibáñez, S, N. (2011). Aprendizaje-enseñanza: Mejora a partir de la interacción de los actores (Learning-teaching: Improvement from the interaction of the actors). Revista Educación y Educadores. 14(3), 457-474. Retrieved from http://www.scielo.org.co/pdf/eded/v14n3/v14n3a02.pdf

Juárez, L. C. (2010). Predictores del comportamiento de reciclaje en alumnos de educación primaria en México (Predictors of recycling behavior in primary school students in Mexico). Psyecology, 1(1), 25-37.

Sánchez, J. (2014). Contextualización y enfoques en el estudio de comportamientos proambientales o ecológicos con miras a la perfilación del consumidor verde (Contextualization and approaches in the study of pro-environmental or ecological behaviors with a view to profiling the green consumer). Suma de Negocios, 5(10), 34-39. Doi: https://doi.org/10.1016/S2215-910X(14)70007-2 
Secretaria de Educación Pública (2016). El Modelo Educativo 2016. Planteamiento pedagógico de la reforma educativa (Educational Model 2016. Pedagogical approach to educational reform). Ciudad de México.

Secretaria de Educación Pública. (2017). Modelo Educativo para la Educación Obligatoria (Educational Model for Compulsory Education). Secretaria de Educación Pública. Ciudad de México.

Schmitz, G. L., \& Rocha, J. B. T. (2018). Environmental education program as a tool to improve children's environmental attitudes and knowledge. Education, 8(2), 1520.

Stern, M. J., Powell, R. B., \& Hill, D. (2014). Environmental education program evaluation in the new millennium: what do we measure and what have we learned? Environmental Education Research, 20(5), 581-611. Doi: https://doi.org/10.1080/13504622.2013.838749

Páez, S. \& Puig, R. (2015). La reflexión en el Aprendizaje-Servicio (Reflection in Service-Learning). Revista internacional de educación para la justicia social, 2 (2). Retrieved from https://revistas.uam.es/riejs/article/view/370

Paco, A., \& Lavrador, T. (2017). Environmental knowledge and attitudes and behaviours towards energy consumption. Journal of environmental management, 197, 384-392.

Palacios, D, J., \& Bustos, A, J. (2012). Modelo de autoeficacia y habilidades ambientales como predictores de la intención y disposición proambiental en jóvenes (Model of self-efficacy and environmental skills as predictors of proenvironmental intention and disposition in young people). Revista Intercontinental de Psicología y Educación, 14 (2). Retrieved from https://www.redalyc.org/pdf/802/80225867001.pdf

Perrenoud, P. (2009). Enfoque por competencias, ¿una respuesta al fracaso escolar? (Competency approach, a response to school failure?) Pedagogía social: revista interuniversitaria, (16), 45-64. Retrieved from https://www.redalyc.org/pdf/1350/135012677004.pdf

Terrón, A. E. (2019). Esbozo de la educación ambiental en el currículum de educación básica en México. Una retrospectiva de los planes y programas de estudio (Outline of environmental education in the basic education curriculum in Mexico. A retrospective of study plans and programs). Revista Latinoamericana De Estudios Educativos, 49(1), 315-346. Retrieved from https://rlee.ibero.mx/index.php/rlee/article/view/42

Terrón, A. E., \& González, G. E. (2009). Representación y Medio Ambiente en la Educación Básica en México (Representation and Environment in Basic Education in Mexico). Pesquisa em Educação Ambiental, 11(28), 2-12. Retrieved from http://www.periodicos.rc.biblioteca.unesp.br/index.php/pesquisa/article/view/61 $\underline{77}$

Touguinha, S., \& Pato, C. (2011). Valores personales, creencias ambientales y comportamiento ecológico de trabajadores brasileños (Personal values, environmental beliefs and ecological behavior of Brazilian workers). Quaderns de psicología, 13(1), 35-45. doi: https://doi.org/10.5565/rev/qpsicologia.918

Torres, R., Mesina, C., Salamanda, S. \& Sepúlveda, S. (2016). Efectos de la enseñanza interdisciplinaria en la educación ambiental sobre los conocimientos, valores y actitudes ambientales de estudiantes de segundo ciclo básico (Los Ángeles, Región del Biobío, Chile) (Effects of interdisciplinary teaching in environmental education on the environmental knowledge, values and attitudes of second cycle students). Revista Complutense de Educación, $27(3), 1139-1155$. 


\title{
İlköğretim Meksikalı Öğrencilerinde Öğretim Uygulaması ve Çevre Yanlısı Davranışların Yapısal Modeli
}

\author{
Giovana Rocío Díaz Grijalva* \\ Institute Technological of Sonora, Ciudad Obregón, Mexico \\ Beatriz Camarena Gómez \\ Center of Research in Food and Development, Hermosillo, Mexico \\ Daniel González Lomelí \\ University of Sonora, Hermosillo, Mexico \\ Carlos Alberto Mirón Juárez \\ Institute Technological of Sonora, Ciudad Obregón, Mexico
}

Received:; Accepted:

\begin{abstract}
Özet (Turkish Abstract of Paper)
Meksika'da ilköğretimde entegre çevre eğitiminden neredeyse kırk yıl sonra, öğrencilerin gösterdiği çevresel davranış ile algıladıkları çevre eğitimi arasındaki ilişkiyi kanıtlamak önemlidir, bu nedenle yapısal bir denklem modeli tasarlanmış ve 217 tarafından sağlanan bilgilerle test edilmiştir. Altıncı sınıf öğrencileri. Model, çevre eğitimi uygulaması ile nedenselliği arasında değerler $(0,035)$, beceriler $(0,333)$, tutumlar $(0,269)$ ve çevre yanlısı davranışlar $(0,290)$ ile doğrudan ve pozitif olarak regresyon katsayılarını göstermiştir. Okullarda çapraz olarak öğretilen çevre eğitiminin önemli olduğu ve çocuklarda çevresel tutum, beceri ve değerleri teşvik etmeye odaklanan materyal, kurumsal destek ve didaktik kaynakların kullanımında öğretim uygulamasının teşvik edilmesi gerektiği doğrulanmıştır.
\end{abstract}

Anahtar Kelimeler: Çevre eğitimi, öğretim uygulaması, çevre yanlısı davranış, öğrenciler. 